\title{
ENTREPRENEURS IN WHITE-COLLAR CRIME: A CONVENIENCE PERSPECTIVE
}

\author{
Petter GOTTSCHALK \\ BI Norwegian Business School
}

\begin{abstract}
White-collar crime can be a convenient alternative for privileged individuals who want to enrich themselves. Their occupational positions enable them to commit and conceal offenses among legal activities. This is especially the case, when the offender has sole responsibility for entrepreneurial tasks that involve substantial amounts of money, as illustrated by the four executives presented in this article. One simple learning point from this article is that nobody - including chair persons, chief executives, and presidents - should ever have sole responsibility for tasks involving money on behalf of the organization.
\end{abstract}

\section{KEYWORDS}

Deviant behavior, organizational opportunity, white-collar crime, convenience theory, agency theory.

\section{BIOGRAPHY}

Petter Gottschalk is professor in the department of leadership and organizational behavior at BI Norwegian Business School in Oslo, Norway. He has been the chief executive at several companies. Dr. Gottschalk has published extensively on internal investigations, knowledge management, and white-collar crime.

\section{INTRODUCTION}

Entrepreneurs are often seen as important economic agents, driving forward employment, opportunities and economic development. Entrepreneurship is associated with innovation, adaptation, change and dynamism, hard work, willpower, and overcoming challenges and struggles. According to Welter et al. (2017), entrepreneurship is a broadly available social technology for creating organizations that may pursue a myriad of goals. They argue that entrepreneurship research can and should be a window into and a tool for shaping social and economic equity.

In this line of reasoning, financial crime by white-collar criminals is an alternative tool for pursuing a large spectrum of social and economic goals. A typical example is corruption, where entrepreneurs on behalf of the organization bribe vendors, public officials and others to achieve

\footnotetext{
${ }^{1}$ Corresponding address: Department of Leadership and Organizational Behavior, BI Norwegian Business School, Oslo, Norway. Email: petter.gottschalk@bi.no
} 
goals. Another example is embezzlement, where entrepreneurs abuse their positions in organizations to enrich themselves.

In this article, we present four case studies from Norway, where entrepreneurship was exercised by key executives for personal benefit. All case studies have in common that executives enriched themselves through embezzlement when they had exclusive rights in money matters for the organization. After a relevant literature review on entrepreneurship (Tonoyan et al., 2010), a description of white-collar crime (Sutherland, 1939), and a presentation of convenience theory (Gottschalk, 2017), then four case studies are presented and discussed in this article. The purpose is to demonstrate how executives apply their entrepreneurial skills to gain personal profit by abusing their organizational positions. In the discussion section, cases are discussed in terms of principals and agents according to agency theory (Bosse and Phillips, 2016).

\section{LITERATURE REVIEW}

Tonoyan et al. (2010) explored the determinants of corruption in transition economies and looked at the East-West gap in corruption in Europe. They found that viewing illegal business activities as a widespread business practice provides the rationale for entrepreneurs to justify their own corrupt activities. Moreover, closed social networks with family, friends, and national bureaucrats reduce the opportunism of the contracting party of the corrupt deal, thus providing breeding grounds for corruption.

Eddleston and Kidwell (2012) studied deviant behavior in family firms that violates organizational norms. Examples are theft, embezzlement and corruption. Given that only $30 \%$ of family firms make it to the second generation, understanding how parents encourage children to act in deviant ways in the firm seems important. Rather than focusing on the child's personality as the cause of deviance, the study shows the importance of examining family relationships.

Entrepreneurs in white-collar crime demonstrate deviant behavior. Similar to moral entrepreneurs as discussed by Ryan (1994), white-collar crime requires both "technicians" who develop techniques of business-level enforcement of rules; and "interpreters", who legitimate the work of technicians by providing expansive readings of applicable legal limitations.

Entrepreneurs in white-collar crime are different from criminal entrepreneurs, when criminal entrepreneurs are defined as entrepreneurs who are mainly on the wrong side of the law in their business endeavors. Entrepreneurs in white-collar crime demonstrate deviant behavior to benefit the organization, often labelled corporate crime, or to benefit the individual, often labelled occupational crime (Kang and Thosuwandchrot, 2017). McElwee and Smith (2015) argue that illegal and criminal entrepreneurship is particularly context specific, where they operate in the shadow economy. The shadow economy comprises those economic activities and the income derived from them that circumvent or otherwise avoid government regulation, taxation or observation (Schneider and Williams, 2013).

\section{WHITE-COLLAR CRIME}

Sutherland's (1939) concept of white-collar crime stresses the importance of crime of the powerful and influential members of the elite in society. Sutherland emphasized the disproportionate extent of harm caused by the crime of the wealthy in comparison to the much researched and popular focus on crime by the poor, and the equally disproportionate level of social control responses. White-collar crime is defined in its relationship to status, opportunity, and access. This is the 
offender-based perspective. In contrast, offense-based approaches to white-collar crime emphasize the actions and nature of the illegal act as the defining agent. In their comparison of the two approaches, Benson and Simpson (2015) discuss how offender-based definitions emphasize societal characteristics such as high social status, power, and respectability of the actor. Because status is not included in the definition of offense-based approaches and status is free to vary independently from the definition in most legislation, an offense-based approach allows measures of status to become external explanatory variables.

In the offender-based perspective, white-collar criminals tend to possess many characteristics that are consistent to expectations of high status in society. There is both attained status and ascribed status among white-collar offenders. Attained status refers to status that is accrued over time and with some degree of effort, such as education and income. Ascribed status refers to status that does not require any specific action or merit but rather is based on more physically observable characteristics, such as race, age, and gender.

The main offender characteristics remain privilege and upper class. Early perception studies suggest that the public think that white-collar crime is not as serious as other forms of crime. Most people think that street criminals should receive harsher punishments. One explanation for this view is selfinterest (Dearden, 2017: 311):

Closely tied to rational choice, self-interest suggests that people have views that selfishly affect themselves. Significant scholarly research has been devoted to self-interest-based views. In laboratory conditions, people often favor redistribution taxes when they would benefit from such a tax. This self-interest extends into non-experimental settings as well. For example, smokers often view increasing smoking taxes less favorably than non-smokers.

In this line of thinking, people may be more concerned about burglary and physical violence that may hurt them. They may be less concerned about white-collar crime that does not affect them directly. Maybe those who are financially concerned with their own economic well-being will be more concerned with white-collar crime (Dearden, 2017).

\section{THEORY OF CONVENIENCE}

As suggested by Gottschalk (2017), white-collar crime can be a convenient option to avoid threats and exploit opportunities. Convenience is a concept that was theoretically mainly associated with efficiency in timesaving. Today, convenience is associated with a number of other characteristics, such as reduced effort and reduced pain. Convenience is associated with terms such as fast, easy, and safe. Convenience says something about attractiveness and accessibility (Sundström and Radon, 2015).

Convenience is characterized by some comfortable practicality. It is simple and not necessarily bad or illegal. For example, ship-owners can register their boats under flags of convenience, which is to sail under false flags to reap economic benefits that might otherwise not be achievable. Convenience can be tricking out without traces of obvious crime, lying in the gray zone and exploiting the system for organizational or personal gain and pleasure. Convenience can be to cause enrichment in an easy and comfortable manner without losing face or reputation (as long as offender is not revealed). In academic research, some researchers use convenience samples for their empirical studies, which consist of readily available respondents. The selection is not random and cannot be said to be representative of the population. It is unacceptable to generalize research results based on such convenience samples. Another example is the convenience store in terms of a 
grocery shop or a gas station, where consumer goods are easily available and accessible, but prices are higher and the selection is more limited (Sari et al., 2017).

Convenience orientation is the value that individuals and organizations place on actions with inherent characteristics of saving time and effort. Convenience orientation is a value-like construct that influences behavior and decision-making. Mai and Olsen (2016) measured convenience orientation in terms of a desire to spend as little time as possible on the task, in terms of an attitude that the less effort needed the better, as well as in terms of a consideration that it is a waste of time to spend a long time on the task. Convenience orientation toward illegal actions increases as negative attitudes towards legal actions increase. The basic elements in convenience orientation are the executive attitudes toward the saving of time, effort and discomfort in the planning, action and achievement of goals. Generally, convenience orientation is the degree to which an executive is inclined to save time and effort to reach goals. Convenience orientation refers to person's general preference for convenient maneuvers. A convenience-oriented person is one who seeks to accomplish a task in the shortest time with the least expenditure of human energy (Berry et al., 2002).

The actual convenience is not necessarily important in convenience theory. Rather, the perceived, expected and assumed convenience influences choice of action. Berry et al. (2002) make this distinction explicit by conceptualizing convenience as individuals' time and effort perceptions related to an action. White-collar criminals probably vary in their perceived convenience of their actions. Low expected convenience could be one of the reasons why not more members of the elite commit white-collar offenses.

Opportunism is part of convenience theory, where opportunism can be defined as self-interested behavior with guile.

\section{CASE STUDIES}

In the following, four case studies of convicted offenders illustrate entrepreneurs in white-collar crime based on convenience theory. Table 1 lists the four cases. The two first cases are presented extensively since there are internal investigations reports publicly available.

\begin{tabular}{|l|l|l|l|l|}
\hline $\begin{array}{l}\text { White-Collar } \\
\text { Criminal }\end{array}$ & $\begin{array}{l}\text { White-Collar } \\
\text { Crime }\end{array}$ & $\begin{array}{l}\text { Economical } \\
\text { Dimension } \\
\text { Motive }\end{array}$ & $\begin{array}{l}\text { Organizational } \\
\text { Dimension } \\
\text { Opportunity }\end{array}$ & $\begin{array}{l}\text { Behavioral } \\
\text { Dimension } \\
\text { Deviance }\end{array}$ \\
\hline $\begin{array}{l}\text { Are Blomhoff } \\
\text { Priest } \\
52 \text { years old }\end{array}$ & $\begin{array}{l}\text { Embezzlement } \\
\text { Betanien } \\
\text { Foundation } \\
\text { 3 years prison } \\
\text { private to buy } \\
\text { apartment and } \\
\text { expensive } \\
\text { parties }\end{array}$ & $\begin{array}{l}\text { Exclusive } \\
\text { responsibility } \\
\text { for money } \\
\text { transfers } \\
\text { between mother } \\
\text { company and } \\
\text { subsidiary }\end{array}$ & $\begin{array}{l}\text { Different } \\
\text { behavior } \\
\text { Spain from } \\
\text { Norway }\end{array}$ \\
\hline $\begin{array}{l}\text { Lars Brorson } \\
\text { CFO years old }\end{array}$ & $\begin{array}{l}\text { Embezzlement } \\
\text { Badeland }\end{array}$ & $\begin{array}{l}\text { Greed to buy } \\
\text { expensive } \\
\text { property and } \\
\text { consumer goods }\end{array}$ & $\begin{array}{l}\text { Exclusive } \\
\text { responsibility } \\
\text { for } \\
\text { transfers money } \\
\text { between } \\
\text { Norway and } \\
\text { Spain }\end{array}$ & $\begin{array}{l}\text { Blamed lacking } \\
\text { control and } \\
\text { mechanisms for } \\
\text { his fraud }\end{array}$ \\
\hline Marius Schatvet & Embezzlement & Divorced and & Exclusive & Dissatisfied with \\
\hline
\end{tabular}




\begin{tabular}{|l|l|l|l|l|}
\hline $\begin{array}{l}\text { CFO } \\
50 \text { years old }\end{array}$ & $\begin{array}{l}\text { Aschehoug } \\
\text { Publishing } \\
\text { 3 years prison }\end{array}$ & $\begin{array}{l}\text { wanted to keep } \\
\text { house and cabin }\end{array}$ & $\begin{array}{l}\text { responsibility } \\
\text { for money } \\
\text { transfers in } \\
\text { chain of } \\
\text { bookstores }\end{array}$ & $\begin{array}{l}\text { his salary level, } \\
\text { where owner } \\
\text { made much } \\
\text { more than him }\end{array}$ \\
\hline $\begin{array}{l}\text { Kjell Staddeland } \\
50 \text { years old }\end{array}$ & $\begin{array}{l}\text { Embezzlement } \\
\text { Ugland Shipping }\end{array}$ & $\begin{array}{l}\text { Greed to live in } \\
\text { the best house } \\
\text { with parking } \\
\text { space for 5 cars }\end{array}$ & $\begin{array}{l}\text { Exclusive } \\
\text { responsibility } \\
\text { for money moner } \\
\text { transfers in joint } \\
\text { venture }\end{array}$ & $\begin{array}{l}\text { Dissatisfied with } \\
\text { his salary level, } \\
\text { where owner } \\
\text { made much than } \\
\text { him }\end{array}$ \\
\hline
\end{tabular}

Table 1 White-collar criminals convicted of convenient embezzlement in Norway

Are Blomhoff was educated as a priest and became chief executive officer (CEO) at the religiouslybased social foundation Betanien in Bergen, Norway. The foundation operates several nursing homes, kindergartens and health institutions associated with the Methodist Church. When he was 52 years old, CEO Blomhoff was in charge of developing a nursing home in Spain for older Norwegians. He got money transferred from Spain to Norway for the project. He had exclusive responsibility for all money transfers to Spain. He embezzled some of the transferred money to buy himself an apartment in Spain and to arrange expensive parties with prostitutes in Spain. Two whistleblowers in Spain sent notice to the chairman at Betanien in Norway, but the chairman would not believe that a priest could do such a thing. When the whistleblowers threatened to tell Norwegian media about the case, then the chairman confronted the CEO with the allegations, and Blomhoff confessed to embezzlement. Fraud examiners from accounting firm BDO (2014) were hired by the chairman to find out if there was more money embezzled by the CEO than he already had confessed. The private investigators found evidence of more embezzlement. In terms of convenience theory, we find evidence of all three dimensions:

1. Motive in the economical dimension: Greed to buy private apartment and expensive parties in Spain. While being a priest and CEO in Norway, he had suppressed all his desires for a wild life that could be enabled by money. Finally, he could enjoy life the way he really wanted.

2. Opportunity in the organizational dimension: Exclusive responsibility for money transfers and no control by others. He was handling large sums of money for the construction project, and only an invisible fraction of the money was taken by him. He did not really conceal his illegal transactions, but he knew that nobody else had access to the relevant accounts. The abused accounts were neither part of the Betanien Foundation in Norway nor the Fundacion Betanien in Spain. Money transfers from Norway were conducted by employees after instructions from the CEO. The transfers were based on fake offers and invoices from Spanish suppliers. Blomhoff got travel and other personal expenses refunded by both Stiftelsen Betanien and Fundacion Betanien. Some of the money transfers occurred via a bank account in Luxembourg.

3. Deviance in the behavioral dimension: Different behavior in Spain from Norway. He would never have done it at home. While in Spain, he became a different person and was willing to embezzle money and hire prostitutes for parties with friends. His willingness increased as he did not notice any damage or any victims of his crime. Blomhoff had problems with substance abuse, which was noticed by the whistleblowers.

In the report of investigation, fraud examiners at BDO (2014: 7) write: "According to the assessment of BDO, the Foundations organizational and internal control is characterized by a situation where the chief executive has enjoyed substantial trust among board members and employees of the foundation and thus had wide powers".. 
Fraud examiners also criticize the board for not reacting timely to whistleblowing and to other information (BDO, 2014: 10):

Information has come to our attention about a safe that was removed from the former CEO's house in Spain, in addition to another safe that was allegedly stolen during a burglary. This happened in the days after the former CEO was confronted with the embezzlement claims. It is our opinion that the case could possibly have been far better documented if the board had chosen to contact the police before the former CEO was confronted with the issue.

Lars Brorson was chief financial officer (CFO) at Hadeland Broadband, a subsidiary of Hadeland Energy. He came from a position at Hadeland Energy and had for a long time been in charge of financial transaction between Hadeland Energy and Hadeland Broadband. Brorson sent, according to investigators from PwC (2014), a total of 18 million Norwegian kroner (about US \$3 million) to his own accounts from Hadeland Broadband's overdraft account. Half of the amount was transferred in 2012, divided into 42 payments. Between 2011 and 2014, 66 such transactions were recorded.

During the same period, the Deloitte auditor wrote that financial statements were prepared in accordance with Norwegian laws and regulations. Auditor Ragnar Nesdal was one of six from Deloitte interviewed by investigator Gunnar Holm Ringen at auditing firm PwC (2014). In the interview, Nesdal felt that the company was so small that there was no requirement for annual meetings between the board and the company's auditors in accordance with Norwegian auditing act. The auditor had not attended board meetings or general assembly meetings. The only communication with the board had therefore been through written auditing statements from Deloitte.

For a long time, the PwC (2014) report was attempted to be kept secret for the public. The local newspaper Hadeland was active in getting disclosure. The newspaper argued for transparency and wrote in its editorial on July 13, 2014:

The newspaper Hadeland has requested access to investigation reports prepared after the embezzlement in Hadeland and Rngerike Broadband (HRB) and Hadeland Energy (HE). The answer has been no, by referencing to the Norwegian freedom of information act section 24 , which states that documents can be exempted if they deal with offenses.

Finally, the owners agreed to public insight into the report. Soon after, Lars Brorson was convicted in Norwegian district court to 4 years and 6 months in prison. In terms of convenience theory, we find evidence of all three dimensions:

1. Motive in the economical dimension: Personal finances were a mess. He wanted to impress his new girlfriend, and he enjoyed the luxury himself. He bought expensive cars, a cabin, and a house, and he maintained a high consumption of expensive cognacs and other consumer goods.

2. Opportunity in the organizational dimension: In charge of financial matters between parent and daughter companies. Since he came from a position in the parent company Hadeland Energy, nobody at the subsidiary Hadeland Broadband dared to question his actions or behavior. They all assumed that Brorson had good contacts at the highest levels in Hadeland Energy, and that people at the highest levels had approved his way of doing financial management. Brorson had himself introduced formal routines at Hadeland Broadband while at Hadeland Energy, and he followed those routines when he joined Hadeland Broadband.

3. Deviance in the behavioral dimension: Lack of control by auditor invited him to commit fraud. He applied the neutralization technique that no damage had occurred as Hadeland Broadband still made a substantial profit. He admitted to lack of self-control when he explained himself in the court. The impression in the court room was that Brorson perceived himself as a victim of his own desires and lack of self-control. 
The Brorson case was uncovered on March 10, 2014, in connection with police investigations of another firm for tax and accounting offenses in a neighboring police district. Lars Brorson had done accounting for this firm in addition to his job as CFO at Hadeland Broadband. He was also charged for these offenses, making the total add up to more than 20 million NOK. During the police investigation, it became known that Brorson had been convicted of embezzlement before, in combination with tax evasion, and that he had spent three years behind bars for it. The previous offense was committed while he was management for hire. It turned out that board members at Hadeland Energy were familiar with Brorson's past economic crime when he was hired in 2009.

Marius Schatvet was chief financial officer at publishing house Aschehoug. When he was alone in the entrepreneurial task of refinancing the publishing house's involvement in a chain of bookstores, he was able to transfer some of the money to his own account without anybody noticing. He did so for many years. Unfortunately for him, he finally typed in his own bank account number with a wrong digit, thereby creating attention. An employee in the accounting department noticed the transaction and blew the whistle on CFO Schatvet. Schatvet was sentenced to 3 years in prison (Silvolva et al., 2014).

Kjell Rune Staddeland was chief executive officer at Ugland Shipping. The Ugland family had owned the company for generations, and the family was rich. Staddeland made the family even richer, while at the same time receiving a modest CEO compensation. When he was handling an entrepreneurial joint venture agreement for the company on his own, he found a way to embezzle. After a while, however, he did regret his crime and told the owner, who reported Staddeland to the police (Berglihn and Fosse, 2013).

\section{DISCUSSION}

Agency theory suggests that problems occur between principal and agent when there are (i) conflicting preferences, (ii) different knowledge and information, and (iii) different attitudes towards risks (Bosse and Phillips, 2016). In their entrepreneurial activities, the sample of four convicted executives abused their powers. Mr. Blomhoff at Betanien was charged with the entrepreneurial task of establishing a nursing home in Spain. Mr. Brorson at Hadeland was charged with the entrepreneurial task of running broadband development while interacting with the energy company. Mr. Schatvet at Aschehoug was to reorganize the publishing house's involvement in a chain of bookstores, while Mr. Staddeland at Ugland was to reshape a joint venture. In all four cases, there were alone in the endeavor. In all four cases, the executives enriched themselves by committing white-collar crime and concealing their illegal transactions among legal transactions.

Obviously, the first problem in the agency relationship occurred, since no principal has a preference for embezzlement by agents. The second problem in principal-agent theory is the dominating one in the cases, where the principal had little or no means to control what the agent was doing. The third and final problem in agency theory seems less relevant, as the action of embezzlement is not a matter of risk where principal and agent disagree.

Based on this article, there are several avenues for future research. First, there should be a stronger link between the study of white-collar crime and entrepreneurship. Second, there is a need to develop new theory and test existing theory by combining convenience theory and agency theory. Third, research questions or research propositions should be developed based on this exploratory research. Finally, future case study research should enable some forms of generalization. An adequate explanation if needed for how future researchers select their case studies, what information they seek to extract, what information they are able to obtain, and how they analyze the data.

\section{CONCLUSION}


White-collar crime is a convenient alternative for privileged individuals who want to enrich themselves. Their occupational positions enable them to commit and conceal offenses among legal activities. This is especially the case, when the offender has sole responsibility for a task involving substantial amounts of money, as illustrated by the four executives presented in this article. One simple learning point from this article is that nobody - including chair persons, chief executives, and presidents - should ever have sole responsibility for tasks involving money on behalf of the organization. Interest divergence and information asymmetry require that the principal monitors the agent to reduce information asymmetry and provide incentives to align interests.

\section{REFERENCES}

BDO (2014). Gransking av Stiftelsen Betanien Bergen (Examination of the Foundation Betanien Bergen) - Anonymisert og revidert sammendrag (Anonymised and revised summary), auditing firm BDO, Oslo, Norway.

Benson, M.L. and Simpson, S.S. (2015). Understanding white-collar crime: An opportunity perspective, Routledge, NY: New York.

Berglihn, H. and Fosse, S.S. (2013). Meldte seg selv (Reported himself), daily Norwegian business newspaper Dagens Nceringsliv, Tuesday, July 9, pages 8-9.

Berry, L.L., Seiders, K. and Grewal, D. (2002). Understanding service convenience, Journal of Marketing, 66, 1-17.

Bosse, D.A. and Phillips, R.A. (2016). Agency theory and bounded self-interest, Academy of Management Review, 41 (2), 276-297.

Dearden, T.E. (2017). An assessment of adults' views on white-collar crime, Journal of Financial Crime, 24 (2), 309-321.

Eddleston, K.A. and Kidwell, R.E. (2012). Parent-Child Relationships: Planting the Seeds of Deviant Behavior in the Family Firm, Entrepreneurship: Theory \& Practice, 36 (2), 369-386.

Gottschalk, P. (2017). Convenience in white-collar crime: Introducing a core concept, Deviant Behavior, 38 (5), 605-619.

Kang, E. and Thosuwanchot, N. (2017). An Application of Durkheim's Four Categories of Suicide to Organizational Crimes, Deviant Behavior, 38 (5), 493-513.

McElwee, G. and Smith, R. (2015). Exploring Criminal and Illegal Enterprise: New Perspectives on Research, Policy \& Practice, Contemporary Issues in Entrepreneurship Research, 5, 3-22.

PwC (2014). Hadeland og Ringerike Bredbånd. Rapport - gransking (Hadeland and Ringerike Broadband. Report-investigation), auditing firm PricewaterhouseCoopers, Oslo, Norway.

Ryan, K. (1994). Technicians and interpreters in moral crusades: The case of the drug courier profile, Deviant Behavior, 15 (3), 217-240. 
Sari, Y.K., Shaari, Z.H. and Amar, A.B. (2017). Measurement development of customer patronage of petrol station with convenience store, Global Business and Management Research: An International Journal, 9 (1), 52-62.

Schneider, F. and Williams, C.C. (2013). The Shadow Economy, The Institute of Economic Affairs, London, UK.

Silvola, N.M., Jonassen, T.H. and Grønneberg, A. (2014). Aschehoughs finansdirektør dømt for underslag(Aschehoug's finance director sentenced for embezzlement), daily Norwegian newspaper Dagbladet, www.dagbladet.no, published December 3.

Sundström, M. and Radon, A. (2015). Utilizing the concept of convenience as a business opportunity in emerging markets, Organizations and Markets in Emerging Economies, 6 (2), 7-21.

Sutherland, E.H. (1939). White-collar criminality. American Sociological Review, 5: 1-12.

Tonoyan, V., Strohmeyer, R., Habib, M. and Perlitz, M. (2010). Corruption and Entrepreneurship: How Formal and Informal Institutions Shape Small Firm Behavior in Transition and Mature Market Economies, Entrepreneurship: Theory \& Practice, 34 (5), 803-831.

Welter, F., Baker, T., Audretsch, D.B. and Gartner, W.B. (2017). Everyday Entrepreneurship - A Call for Entrepreneurship Research to Embrace Entrepreneurial Diversity, Entrepreneurship: Theory and Practice, 41 (3), 323-347. 